\title{
PENGARUH JENIS MULSA ORGANIK DAN KEPADATAN CACING TANAH TERHADAP SIFAT KIMIA DYSTRUDEPTS
}

\author{
Khaiun Nisa ${ }^{*}$, Wawan², Anthony Hamzah² \\ ${ }^{1}$ Program Studi Ilmu Pertanian, Fakultas Pertanian, Universitas Riau, Kampus Bina Widya Jalan H.R \\ Soebrantas Km. 12,5 Simpang Baru Pekanbaru 28293, Indonesia \\ ${ }^{2}$ Universitas Riau, Kampus Bina Widya Jalan H.R Soebrantas Km. 12,5 Simpang Baru Pekanbaru 28293, \\ Indonesia
}

Email : Khairunnisaanis17@gmail.com

\begin{abstract}
Studies on the combination of organic mulch and earthworms density on the chemical properties of Dystrudepts are scares. This study aims to determine the effect and determine the type of organic mulch, earthworm density, and combinations that produce the best chemical properties of Dystrudept. This research was carried out in the oil palm plantation area of the Agriculture Experiment Station, The Faculty of Agriculture Universitas Riau. This study was a $3 \times 4 \times 3$ factorial experiment which was placed according to a split plot design. This study was divided into 3 main plots and 4 subplots which were repeated 3 times. The main plot is 3 type of organic mulch, namely: M1 (Mucuna bracteata), M2 (oil palm empty fruit bunches) and M3 (oil palm midrib). Sub plot is the density of earthworms consisting of 4 levels, namely C0: without worms, C1: 35 worms $/ \mathrm{m}^{2}, \mathrm{C} 2: 50$ worms $/ \mathrm{m}^{2}, \mathrm{C} 3$ : 65 worms $/ \mathrm{m}^{2}$. The data were analyzed using analysis of variance and to determine the difference between the average of the treatment was tested by Duncan's at 5\% significance level. The results of the researched showed that MB organic mulch produced higher Corganic, total $\mathrm{N}$ and lower $\mathrm{C} / \mathrm{N}$ ratio compared to OPEFB and OPM. OPEFB produces total $\mathrm{K}$, $\mathrm{K}$-dd which is higher than MB and OPM. OPM produces $\mathrm{pH}, \mathrm{P}$ available, $\mathrm{Na}$ - $\mathrm{dd}$ is higher than $\mathrm{MB}$ and OPEFB. The density of worms 50 worms $/ \mathrm{m}^{2}$ increases the $\mathrm{pH}, \mathrm{Mg}$-dd. The combination of MB organic mulch and earthworm density of 65 worms $/ \mathrm{m}^{2}$ produces higher Corganic, $\mathrm{N}$-total, $\mathrm{P}$ available and lower $\mathrm{C} / \mathrm{N}$ ratio compared to other combinations.
\end{abstract}

Keywords: Chemichal Soil Properties, Dystrudepts, Earthworms, Organic Mulch.

\begin{abstract}
Abstrak
Studi tentang kombinasi jenis mulsa organik dan kepadatan cacing tanah terhadap sifat kimia Dystrudepts di bawah tegakan kelapa sawit masih terbatas. Penelitian ini bertujuan untuk mengetahui efek dan menentukan jenis mulsa organik, kepadatan cacing tanah, serta kombinasi yang menghasilkan sifat kimia Dystrudept terbaik. Penelitian ini dilakukan di area perkebunan kelapa sawit di Stasiun Percobaan Pertanian, Fakultas Pertanian Universitas Riau. Penelitian ini adalah percobaan faktorial $3 \times 4 \times 3$ yang ditempatkan menurut Split Plot Design. Penelitian ini dibagi menjadi 3 petak utama dan 4 anak petak yang diulang 3 kali. Petak utama adalah 3 jenis mulsa organik, yaitu: M1 (Mucuna bracteata), M2 (Tandan Kosong Kelapa Sawit) dan M3 (Pelepah Kelapa Sawit). Anak Petak adalah kepadatan cacing tanah yang terdiri dari 4 level, yaitu C0: tanpa cacing, C1: 35 cacing $/ \mathrm{m}^{2}$, C2: $50 \mathrm{cacing} / \mathrm{m}^{2}$, C3: $65 \mathrm{cacing} / \mathrm{m}^{2}$. Data dianalisis menggunakan analisis ragam dan untuk menentukan perbedaan antara rata-rata perlakuan diuji lanjut dengan Duncan's pada taraf nyata 5\%. Hasil penelitian menunjukkan bahwa mulsa organik MB menghasilkan C-organik, $N$ total, yang lebih tinggi serta nisbah $C / N$ yang rendah dibanding TKKS dan PKS. TKKS menghasilkan $K$ total, $K$-dd yang lebih tinggi dibanding MB dan PKS. PKS menghasilkan $\mathrm{pH}$, P tersedia, Na-dd lebih tinggi dibanding MB dan TKKS. Kepadatan cacing 50 ekor/m² meningkatkan $\mathrm{pH}, \mathrm{Mg}$-dd. Kombinasi mulsa organik MB dan kepadatan cacing 65 ekor/m² menghasilkan C-organik, $N$-total, $P$ tersedia lebih tinggi serta nisbah $C / N$ yang rendah dibanding kombinasi yang lain.
\end{abstract}


Kata kunci: Cacing Tanah, Dystrudepts, Mulsa Organik, Sifat KimiaTanah.

\section{PENDAHULUAN}

Tanah mineral masam di Provinsi Riau yang mendominasi salah satunya adalah Inceptisol dan great groupnya adalah Dystrudepts. Dystrudepts merupakan tanah mineral masam yang memiliki tingkat kejenuhan Al yang tinggi, unsur hara rendah, C-organik rendah, dan bahan organik yang rendah. Dystrudepts yang akan dikembangkan untuk perkebunan kelapa sawit memerlukan pemberian bahan organik (Munir, 1996).

Pengusahaan perkebunan kelapa sawit tidak terlepas dari aktivitas pemeliharaan dan panen. Namun, aktivitas pemeliharaan dan panen serta tumbukan butir hujan dapat menyebabkan tanah menjadi padat (penurunan volume tanah). Pemadatan tanah ini memiliki dampak pada sifat kimia tanah. Dampak terhadap sifat kimia tanah yaitu berpengaruh terhadap serapan hara, terutama $\mathrm{N}, \mathrm{P}$, dan $\mathrm{K}$.

Usaha pengelolaan tanah yang cukup efektif untuk mengatasi pemadatan tanah yaitu dengan cara mekanik, namun hal ini dapat merusak perakaran tanaman dan membutuhkan biaya yang besar. Alternatif untuk mengatasi permasalahan tersebut adalah dengan pemberian cacing tanah (Lumbricus terrestris) disertai aplikasi mulsa organik (Mucuna bracteata, tandan kosong kelapa sawit dan cacahan pelepah kelapa sawit) pada piringan kelapa sawit.

Aktivitas cacing tanah yang melakukan pengolahan tanah dengan cara mencampur bahan organik dan tanah dari lapisan atas hingga lapisan bawah tanah menyebabkan penyebaran unsur hara dalam tanah menjadi rata. Mulsa organik dapat dimanfaatkan menjadi sumber energi karbon bagi cacing tanah sehingga cacing tanah akan aktif mendekomposisi. Hal ini akan memperbaiki sifat kimia tanah karena hasil dekomposisi akan dihasilkan senyawa-senyawa organik yang dapat berperan sebagai sementing agen dalam pembentukan agregat. Pemberian mulsa dapat menjaga kelembaban tanah, mengendalikan suhu, menahan energi kinetik butir hujan dan aliran permukaan. Kombinasi jenis mulsa organik dan kepadatan cacing tanah diharapkan dapat bersinergi sehingga hasil interaksi antara kedua faktor tersebut dapat memperbaiki sifat kimia Dystrudepts serta meningkatkan serapan unsur hara pada tanaman.

Adapun tujuan dari penelitian ini adalah untuk : 1. Mengetahui pengaruh dan menentukan mulsa organik yang menghasilkan perbaikan sifat kimia Dystrudepts. 2. Mengetahui pengaruh dan menentukan kepadatan cacing tanah yang menghasilkan perbaikan sifat kimia Dystrudepts. 3. Mengetahui pengaruh interaksi dan menentukan kombinasi antara mulsa organik dan kepadatan cacing tanah yang menghasilkan perbaikan sifat kimia Dystrudepts.

\section{METODOLOGI PENELITIAN}

\subsection{Bahan}

Bahan yang digunakan selama penelitian ialah tanaman kelapa sawit menghasilkan (TM) yang berumur 12 tahun, biomassa Mucuna bracteata, TKKS dan PKS dan cacing tanah Lumbricus terrestris. Peralatan yang digunakan selama penelitian yaitu, peralatan lapangan seperti mesin pencacah, timbangan, dan bor belgi.

\subsection{Metode}

Penelitian ini dilakukan secara eksperimen menggunakan rancangan petak terbagi (split plot design) dengan rancangan dasar acak kelompok. Penelitian ini terdiri dari 3 petak utama, pada setiap petak utama terdiri 4 anak petak yang diulang sebanyak 3 kali sehingga didapatkan 36 unit plot percobaan. Petak utama (main plot) adalah mulsa organik yang terdiri dari 3 jenis, yaitu : M1 : Mucuna bracteata (MB), M2 : Tandan Kosong Kelapa Sawit (TKKS), M3 : Pelepah Kelapa Sawit (PKS). Anak petak (sub plot) adalah kepadatan cacing tanah yang terdiri dari 4 taraf, yaitu : CO : tanpa cacing tanah, C1 : 35 cacing/ $\mathrm{m}^{2}, \mathrm{C} 2$ : 50 cacing $/ \mathrm{m}^{2}, \mathrm{C} 3: 65$ cacing $/ \mathrm{m}^{2}$.

\subsection{Aplikasi Mulsa Organik dan Cacing Tanah}

Mulsa organik diaplikasikan di piringan (dosis $150 \mathrm{~kg} /$ batang) dengan jarak 1 meter dari batang kelapa sawit dan lebar aplikasi 1 meter mengelilingi piringan. Mulsa organik ditebar merata di piringan hingga menutupi permukaan tanah. Aplikasi mulsa organik dilakukan 2 minggu setelah pembersihan lahan. Pemberian cacing tanah dilakukan di piringan dengan cara disebar pada lapisan 
bawah mulsa organik sesuai perlakuan kepadatan. Cacing tanah spesies Lumbricuss terrestris dewasa diaplikasikan 1 minggu setelah aplikasi mulsa organik.

\subsection{Prosedur Pengambilan Sampel Kimia Tanah dan Metode Analisis}

Pengambilan sampel analisis kimia tanah dilakukan pada akhir penelitian. Titik pengambilan sampel berada di piringan yang telah diberi perlakuan, kemudian bersihkan piringan dari mulsa menggunakan cangkul. Selanjutnya pengambilan sampel tanah terganggu diambil dengan menggunakan bor belgi dengan cara memutar bor belgi pada tanah searah jarum jam pada kedalaman 10-20 cm. Sampel tanah dimasukkan ke dalam plastik dan diberi label sesuai perlakuan. Sebelum dianalisis, sampel tanah dikeringanginkan terlebih dahulu. Sifat kimia tanah dan metode analisis yang digunakan adalah $\mathrm{pH}$ tanah ( $\mathrm{pH}$ meter), C-organik (Walkley and Black), $\mathrm{N}$ total (kjeldhal), C/N ratio (penjumlahan), $\mathrm{P}$ tersedia (Bray II) $<\mathrm{K}$ total (ekstraksi $\mathrm{HCl} 25 \%$ ), basa-basa yang dapat ditukar (ekstrak $\mathrm{NH}_{4} \mathrm{Oac} \mathrm{pH} 7$ ), KTK (ekstrak $\mathrm{NH}_{4} \mathrm{Oac} \mathrm{pH} 7$ ), dan kejenuhan basa (penjumlahan).

\subsection{Analisis Data}

Data yang diperoleh dianalisis menggunakan sidik ragam. Untuk mengetahui perbedaan rerata variabel yang diamati diuji dengan Duncan pada taraf nyata 5\%. Analisis data dilakukan menggunakan program SAS 9.1.

\section{HASIL DAN PEMBAHASAN}

Hasil penelitian menunjukkan bahwa mulsa organik Mucuna bracteata lebih baik dalam memperbaiki beberapa sifat Dystrudepts. Mucuna bracteata (MB) menghasilkan $\mathrm{C}$-organik, $\mathrm{N}$ total yang lebih tinggi serta nisbah $\mathrm{C} / \mathrm{N}$ yang rendah dibanding TKKS dan PKS. MB merupakan mulsa organik yang lebih disukai cacing tanah karena mempunyai tekstur lunak sehingga mudah dicerna dibanding TKKS dan PKS. MB dimanfaatkan cacing tanah sebagai sumber energi untuk melakukan aktivitasnya. Selain itu, cacing tanah menghasilkan kascing yang merupakan hasil dari metabolisme cacing tanah. Kascing memiliki unsur hara nitrogen $(N)$ 0,63\%, fosfor (P) 0,35\%, kalium (K) 0,2\%, kalsium (Ca) $0,23 \%$, mangan (Mn) 0,003\%, magnesium (Mg) 0,26\%, tembaga (Cu) $17,58 \%$, seng $(\mathrm{Zn}) \quad 0,007 \%$, besi (Fe) $0,79 \%$, molibdenum (Mo) $14,48 \%$, bahan organik 0,21\%, KTK 35,80 cmol(+) kg-1, kapasitas menyimpan air 41,23\% dan asam humat 13,88\% (Mulat, 2003). Dengan demikian unsur hara dari kascing tersebut menambah unsur hara di dalam tanah dan memperbaiki sifat kimia Dystrudepts.

Peningkatan $\mathrm{N}$ total pada $\mathrm{MB}$ juga disebabkan karena MB merupakan tanaman legum yang mampu memfiksasi N. Selain itu, MB juga mengandung nitrogen lebih tinggi 3.71\% N (Simamora dan Salundik, 2006), dibanding PKS 2,6-2,9\% N (Syahfitri, 2008), dan TKKS yang hanya memiliki $3.71 \% \mathrm{~N}$ (Ermadani, 2011). Hakim et al. (1986), menyatakan bahwa dekomposisi bahan organik akan menghasilkan senyawa yang mengandung nitrogen. MB akan menghasilkan protein dan asam-asam amino yang diperoleh dari proses dekomposisi. Protein dan asam-asam amino yang diperoleh terusari menjadi ammonium $(\mathrm{NH} 4+)$ dan nitrat (NO3+) yang menyumbang nitrogen terbesar dalam tanah. Hal ini yang kemudian menyebabkan penambahan bahan organik yang mengandung $\mathrm{N}$ tinggi seperti $\mathrm{MB}$ akan meningkatkan $\mathrm{N}$ total tanah karena terjadinya mineralisasi MB. Selain itu, Utami dan Handayani (2003) juga menjelaskan bahwa pemberian bahan organik dapat meningkatkan C-organik tanah sehingga dapat mempengaruhi sifat tanah menjadi lebih baik.

Tabel 1. Rerata sifat kimia tanah yang diaplikasi mulsa organik

\begin{tabular}{|c|c|c|c|}
\hline Main Plot & Mulsa Organik & & \\
\hline $\begin{array}{ll}\text { Sifat } & \text { Kimia } \\
\text { Tanah } & \end{array}$ & $\mathrm{MB}$ & $\begin{array}{c}\text { TKK } \\
\mathrm{S}\end{array}$ & PKS \\
\hline $\mathrm{pH}$ & $4.70 \mathrm{~b}$ & $\begin{array}{c}5.09 \\
a\end{array}$ & $\begin{array}{c}5.20 \\
a\end{array}$ \\
\hline C-Organik (\%) & $3.94 \mathrm{a}$ & $\begin{array}{c}3.19 \\
\mathrm{C}\end{array}$ & $\begin{array}{c}3.66 \\
b\end{array}$ \\
\hline N Total (\%) & $0.29 a$ & $\begin{array}{c}0.22 \\
C\end{array}$ & $\begin{array}{c}0.25 \\
b\end{array}$ \\
\hline $\mathrm{C} / \mathrm{N}$ ratio & $13.63 b$ & $\begin{array}{c}14.5 \\
9 a\end{array}$ & $\begin{array}{l}14.3 \\
9 \mathrm{ab}\end{array}$ \\
\hline P Tersedia (ppm) & $13.26 \mathrm{ab}$ & $\begin{array}{c}10.4 \\
6 \mathrm{~b}\end{array}$ & $\begin{array}{c}15.5 \\
1 \mathrm{a}\end{array}$ \\
\hline $\begin{array}{ll}\mathrm{K} & \text { Total } \\
(\mathrm{mg} / 100 \mathrm{~g}) & \end{array}$ & $57.83 b$ & $\begin{array}{c}65.6 \\
3 a\end{array}$ & $\begin{array}{c}59.7 \\
5 b\end{array}$ \\
\hline $\mathrm{K}-\mathrm{dd}(\mathrm{me} / 100 \mathrm{~g})$ & $0.19 b$ & $\begin{array}{c}0.36 \\
a\end{array}$ & $\begin{array}{c}0.19 \\
b\end{array}$ \\
\hline $\mathrm{Na}-\mathrm{dd}(\mathrm{me} / 100 \mathrm{~g})$ & $0.26 \mathrm{~b}$ & $\begin{array}{c}0.28 \\
a b\end{array}$ & $\begin{array}{c}0.32 \\
a\end{array}$ \\
\hline Ca-dd (me/100g) & $1.20 \mathrm{a}$ & $\begin{array}{c}1.23 \\
a\end{array}$ & $\begin{array}{c}1.23 \\
a\end{array}$ \\
\hline $\begin{array}{l}\text { Mg-dd } \\
(\mathrm{me} / 100 \mathrm{~g})\end{array}$ & $0.79 a$ & $\begin{array}{c}0.88 \\
a\end{array}$ & $\begin{array}{c}0.81 \\
a\end{array}$ \\
\hline KTK $(\mathrm{me} / 100 \mathrm{~g})$ & $19.65 \mathrm{a}$ & $\begin{array}{c}19.1 \\
3 a\end{array}$ & $\begin{array}{c}18.5 \\
4 a\end{array}$ \\
\hline
\end{tabular}


$\begin{array}{llll}\mathrm{KB}(\%) & 12.50 \mathrm{a} & 14.3 & 13.7\end{array}$

Get and Place:

\begin{tabular}{|l|l|l|l|}
\hline weigh & $\begin{array}{l}\text { conditio } \\
\mathrm{t}\end{array}$ & $\begin{array}{l}\text { Place } \\
\text { ns }\end{array}$ & $\begin{array}{l}\text { Cod } \\
\text { accurac }\end{array}$ \\
\hline
\end{tabular}

\begin{tabular}{l|l|l|l|}
$\mathrm{t}$ & $\mathrm{ns}$ & $\begin{array}{l}\text { accurac } \\
\mathrm{y}\end{array}$ & $\mathrm{e}$ \\
\hline & & approx. & $\mathrm{AA}$ \\
\hline
\end{tabular}

\begin{tabular}{|c|c|c|c|}
\hline \multirow{3}{*}{$<=1$} & \multirow[t]{2}{*}{ easy } & Loose & $A B$ \\
\hline & & Tight & $A C$ \\
\hline & & approx. & $A D$ \\
\hline
\end{tabular}

$\mathrm{kg}$

\begin{tabular}{|l|l|l|}
\multirow{3}{*}{ difficult } & approx. & $\mathrm{AD}$ \\
\cline { 2 - 3 } & Loose & $\mathrm{AE}$ \\
\cline { 2 - 3 } & Tight & $\mathrm{AF}$ \\
\hline handful & approx. & $\mathrm{AG}$ \\
\hline
\end{tabular}

\begin{tabular}{|c|c|c|}
\hline & & \\
\hline handful & approx. & $A G$ \\
\hline & approx. & $\mathrm{AH}$ \\
\hline$>1 \mathrm{~kg}<=8 \mathrm{~kg}$ & Loose & AJ \\
\hline & Tight & $\mathrm{AK}$ \\
\hline & approx. & $A L$ \\
\hline$>8 \mathrm{~kg}<=20 \mathrm{~kg}$ & Loose & AM \\
\hline & Tight & AN \\
\hline
\end{tabular}

\begin{tabular}{l|l} 
Place: approx. & PA \\
\hline Place:
\end{tabular}

\begin{tabular}{l|l}
\hline Place: loose & PB \\
\hline Place: tight & PC \\
\hline
\end{tabular}

\begin{tabular}{|l|l} 
Visual control & VA \\
\hline
\end{tabular}

Handel tool:

Get, Place and

Place a side

Operate: one single

operation

Operate: compound $\quad \mathrm{BB}$

\begin{tabular}{l|l} 
operation & \\
Motion cycle: One Motion & ZA
\end{tabular}

Motion cycle: Motion
sequence

\begin{tabular}{|l|l|}
\hline $\begin{array}{l}\text { Shift and 1 Motion with } \\
\text { reposition }\end{array}$ & ZC \\
\hline Fasten or Loosen & ZD \\
\hline Body motion (1 Motion) & $\mathrm{KA}$ \\
\hline Bend, stoop, kneel & $\mathrm{KB}$ \\
\hline Sit and stand & $\mathrm{KC}$ \\
\hline
\end{tabular}

(Angka-angka pada baris dan kolom yang diikuti oleh huruf kecil yang sama menunjukkan tidak berbeda nyata menurut uji lanjut berganda Duncan pada taraf 5\%.

Selain Mucuna bracteata, TKKS dan PKS juga memiliki peran dalam memperbaiki sifat kimia Dystrudepts. TKKS menghasilkan $\mathrm{K}$ total, K-dd yang lebih tinggi dibanding $M B$ dan PKS. Hal ini dikarenakan TKKS memiliki unsur $\mathrm{K}$ lebih tinggi 3,46\% (Simamora dan Slaundik, 2006) dibanding PKS yang memiliki K 1.1-1.3\% (Ermadani, 2011) dan MB yang memiliki K $2.92 \%$ (Syahfitri, 2008). Pemberian bahan organik yang memiliki unsur $\mathrm{K}$ akan meningkatkan $\mathrm{K}$-total dalam tanah (Soepardi, 1983). Sedangkan PKS menghasilkan $\mathrm{P}$ tersedia, $\mathrm{Na-dd}$ lebih tinggi dibanding $\mathrm{MB}$ dan TKKS. Tingginya $\mathrm{P}$ tersedia dikarenakan PKS memiliki unsur hara $P$ lebih tinggi sehingga dapat meningkatkan ketersediaan $\mathrm{P}$ dalam tanah. Berdasarkan hasil penelitian Syahfitri (2008)

PKS memiliki $P$ sebesar $0.16-0.9 \%$ sementara MB memiliki $P$ sebesar $0,38 \%$ (Simamora dan Salundik, 2006) dan TKKS memiliki P sebesar 0,76\% (Ermadani, 2011).

Selain mulsa organik, kepadatan cacing tanah juga memperbaiki beberapa sifat kimia Dystrudepts. Kepadatan cacing tanah 50 ekor/m2 meningkatkan $\mathrm{pH}, \mathrm{Mg}-\mathrm{dd}$. Hal ini diduga pada tingkat kepadatan ini cacing tanah lebih efektif dalam melakukan mendekomposisi dan mineralisasi bahan organik sehingga dapat melepaskan kationkation basa yang lebih tinggi dibanding kepadatan cacing tanah yang lain. Pelepasan kation-kation basa ini menyebabkan $\mathrm{pH}$ tanah menjadi meningkat akibat berkurangnya pengaruh asam-asam organik. $\mathrm{Hal}$ ini sesuai dengan pernyataan Saif (1985) bahwa reaksi tanah yang bersifat masam yang disebabkan oleh ion $\mathrm{H}+$ pada larutan tanah dapat dikurangi dengan menggunakan senyawa yang bersifat basa.

Tabel 2. Rerata sifat kimia tanah yang diaplikasi cacing tanah

\begin{tabular}{|c|c|c|c|c|}
\hline Sub Plot & \multicolumn{4}{|c|}{ Kepadatan Cacing Tanah } \\
\hline $\begin{array}{l}\text { Sifat } \\
\text { Kimia } \\
\text { Tanah }\end{array}$ & $\begin{array}{l}0 \\
\text { ekor/ } \\
\mathrm{m}^{2}\end{array}$ & $\begin{array}{l}35 \\
\text { ekor/ } \\
\mathrm{m}^{2}\end{array}$ & $\begin{array}{l}50 \\
\text { ekor/ } \\
\mathrm{m}^{2}\end{array}$ & $\begin{array}{l}65 \\
\text { ekor/ } \\
\mathrm{m}^{2} \\
\end{array}$ \\
\hline $\mathrm{pH}$ & $4.90 \mathrm{~b}$ & $\begin{array}{l}4.98 \\
a b\end{array}$ & $5.15 \mathrm{a}$ & $4.96 \mathrm{~b}$ \\
\hline $\begin{array}{l}\text { C- } \\
\text { Organik } \\
(\%)\end{array}$ & $3.29 \mathrm{~b}$ & $3.19 \mathrm{~b}$ & $3.94 \mathrm{a}$ & $3.96 \mathrm{a}$ \\
\hline $\begin{array}{l}\mathrm{N} \text { Total } \\
(\%)\end{array}$ & $0.23 b$ & $0.23 b$ & $0.28 a$ & $0.28 \mathrm{a}$ \\
\hline $\mathrm{C} / \mathrm{N}$ & 14.29 & 13.88 & 14.18 & 14.47 \\
\hline $\begin{array}{l}\text { ratio } \\
\mathrm{P}\end{array}$ & a & a & a & a \\
\hline $\begin{array}{l}\text { Tersedia } \\
\text { (ppm) }\end{array}$ & 14.21 & 12.52 & 11.41 & 14.17 \\
\hline $\begin{array}{l}\text { (ppm) } \\
\text { K Total }\end{array}$ & $\mathrm{a}$ & $\mathrm{a}$ & $\mathrm{a}$ & $\mathrm{a}$ \\
\hline $\begin{array}{l}\text { (mg/100 } \\
\mathrm{g})\end{array}$ & $\begin{array}{l}58.82 \\
b\end{array}$ & $\begin{array}{l}65.02 \\
a\end{array}$ & $\begin{array}{l}60.45 \\
b\end{array}$ & $\begin{array}{l}59.99 \\
b\end{array}$ \\
\hline $\begin{array}{l}\text { K-dd } \\
\text { (me/100 }\end{array}$ & & 0.24 & & \\
\hline $\begin{array}{l}\text { g) } \\
\text { Na-dd } \\
\text { (me/100 }\end{array}$ & $0.21 \mathrm{~b}$ & $a b$ & $0.27 \mathrm{a}$ & $0.27 \mathrm{a}$ \\
\hline $\begin{array}{l}\text { g) } \\
\text { Ca-dd } \\
\text { (me/100 }\end{array}$ & $0.29 \mathrm{a}$ & $0.32 \mathrm{a}$ & $0.28 \mathrm{a}$ & $\begin{array}{l}0.28 \mathrm{a} \\
1.17\end{array}$ \\
\hline $\begin{array}{l}\text { g) } \\
\text { Mg-dd }\end{array}$ & $1.08 \mathrm{~b}$ & $1.33 \mathrm{a}$ & $1.30 \mathrm{a}$ & $a b$ \\
\hline$(\mathrm{me} / 100$ & 0.74 & 0.93 & & \\
\hline g) & bc & $a b$ & $0.96 \mathrm{a}$ & $0.67 \mathrm{c}$ \\
\hline KTK & 19.19 & 19.04 & 19.52 & 18.67 \\
\hline $\begin{array}{l}\text { (me/100 } \\
\text { g) }\end{array}$ & a & a & a & a \\
\hline KB (\%) & $\begin{array}{l}12.03 \\
b\end{array}$ & $\begin{array}{l}14.82 \\
a\end{array}$ & $\begin{array}{l}14.43 \\
a\end{array}$ & $\begin{array}{l}12.83 \\
b\end{array}$ \\
\hline
\end{tabular}


Angka-angka pada baris dan kolom yang diikuti oleh huruf kecil yang sama menunjukkan tidak berbeda nyata menurut uji lanjut berganda Duncan pada taraf 5\%

Kombinasi yang menghasilkan perbaikan sifat kimia Dystrudepts adalah kombinasi mulsa organik Mucuna bracteata dan kepadatan cacing 65 ekor/m2. Kombinasi mulsa organik Mucuna bracteata dan kepadatan cacing 65 ekor/m2 tanah menghasilkan C-organik, N-total, P tersedia lebih tinggi dibanding kombinasi yang lain. Seperti yang telah dijelaskan sebelumnya, semakin banyak cacing maka aktivitas cacing dalam tanah juga semakin meningkat. Cacing memanfaatkan bahan organik sebagai sumber makanan sehingga dapat melakukan aktivitasnya. Cacing juga mendekomposisi bahan organik, namun Mucuna bracteata lebih disukai karena memiliki tekstur yang halus serta mengandung $\mathrm{C} / \mathrm{N}$ rendah serta $\mathrm{N}$ tinggi. Hal ini menyebabkan terjadinya perbaikan beberapa sifat kimia Dystrudepts.

\section{KESIMPULAN DAN SARAN}

\subsection{KESIMPULAN}

Berdasarkan hasil penelitian yang telah dilaksanakan, maka dapat diambil kesimpulan sebagai berikut :

1. Mulsa organik MB menghasilkan Corganik, $\mathrm{N}$ total, yang lebih tinggi serta nisbah $\mathrm{C} / \mathrm{N}$ yang rendah dibanding TKKS dan PKS. TKKS menghasilkan $\mathrm{K}$ total, Kdd yang lebih tinggi dibanding $M B$ dan PKS. PKS menghasilkan $\mathrm{pH}, \mathrm{P}$ tersedia, $\mathrm{Na-dd}$ lebih tinggi dibanding MB dan TKKS.

2. Kepadatan cacing 50 ekor $/ \mathrm{m}^{2}$ meningkatkan $\mathrm{pH}, \mathrm{Mg}$-dd.

3. Kombinasi mulsa organik $M B$ dan kepadatan cacing 65 ekor $/ \mathrm{m}^{2}$ menghasilkan C-organik, N-total, $\mathrm{P}$ tersedia lebih tinggi serta nisbah $\mathrm{C} / \mathrm{N}$ yang rendah dibanding kombinasi yang lain

\section{DAFTAR PUSTAKA}

[1] Ermadani., A., Muzar dan I. A Mahbub. 2011. Pengaruh Residu Kompos Tandan Buah Kosong Kelapa Sawit Terhadap Beberapa Sifat Kimia Ultisol dan Hasil Kedelai. Jurnal Penelitian Universitas Jambi Seri Sains. Volume 13, Nomor 2, Hal. 1118. Juli - Desember 2011. Program
Studi Agroekoteknologi Fakultas Pertanian Universitas Jambi. Jambi.

[2] Hakim. N., Nyakpa. Y. M., A.M. Lubis., Nugroho., M.R. Saul., M.A. Diha., G.B. Hong., dan H.H. Bailey. 1986. Dasar-Dasar Ilmu Tanah. Universitas Lampung Press. Bandar Lampung.

[3] Mulat, T. (2003). Membuat dan Memanfaatkan Kascing Pupuk Organik Berkualitas. Jakarta: Agromedia Pustaka.

[4] Munir, M.1996. Tanah-Tanah Utama Di Indonesia, Karakteristik, Klasifikasi dan Pemanfaatannya. Pustaka Jaya. Jakarta. hal.216-238.

[5] Saif. 1985. The Effect Amelioran Kinds And Dosages To Oxisol's Zero Charge Point And Phosphate Retention. http:// jurnal. fp. uns. ac.id/ index. Php /tanah/article/viewFile/111/pdf_11.

Diakses pada 11 Mei 2019.

[6] Simamora, S dan Salundik, 2006. Meningkatkan Kualitas Kompos. Cetakan Pertama. Agromedia Pustaka. Jakarta.

[7] Soepardi, G. 1983. Sifat dan Ciri Tanah. Fakultas Pertanian Institut Pertanian Bogor. Bogor.

[8] Syahfitri., M.,M. 2008. Analisis Unsur Hara Fosfor (P) Pada Daun Kelapa Sawit Secara Spektrofotometri Dipusat Penelitian Kelapa Sawit (PPKS) Medan. Universitas Sumatra Utara. Karya Ilmiah. Tidak Dipublikasikan.

[9] Utami, S.N. dan Handayani, S. 2003. Sifat Kimia Entisol pada Sistem Pertanian Organik. Jurnal Ilmu Pertanian 10 ( 2), 63-69. 